Article

\title{
Performance Evaluation of a Solar-Powered Regenerative Organic Rankine Cycle in Different Climate Conditions
}

\author{
Emily Spayde, Pedro J. Mago * and Heejin Cho \\ Department Mechanical Engineering, Mississippi State University, Starkville, MS 39762, USA; \\ espayde@me.msstate.edu (E.S.); cho@me.msstate.edu (H.C.) \\ * Correspondence: mago@me.msstate.edu; Tel.: +1-662-325-3260
}

Academic Editor: Roberto Capata

Received: 10 October 2016; Accepted: 10 January 2017; Published: 13 January 2017

\begin{abstract}
A model to evaluate the performance of a solar powered regenerative Organic Rankine Cycle (R-ORC) using five dry organic fluids: RC318, R227ea, R236ea, R236fa, and R218, is presented in this paper. The system is evaluated in two locations in the U.S.: Jackson, MS and Tucson, AZ. The weather data for each location is used to determine the heat available from the solar collector that could be used by the R-ORC to generate power. Results from the R-ORC performance are compared with a basic ORC using first and second law criteria as well as primary energy consumption (PEC) and carbon dioxide emission (CDE) savings for both locations. An economic analysis to determine the maximum capital cost for a desired payback period is presented in this paper. A parametric analysis is also performed to study the effect of the turbine efficiency as well as the open feed organic fluid heater intermediate pressure on the system performance. Results indicate that the R-ORC is able to generate more power than the basic ORC for some of the selected working fluids. For the R-ORC, R236ea is the working fluid that show the best performance among the evaluated fluids under the modeled conditions. On the other hand, the basic ORC with R236ea as the working fluid outperformed three of the fluids in the R-ORC. Also, the R-ORC evaluated in Tucson, AZ is able to generate more power, to provide more PEC and CDE savings, and had a higher available capital cost than the R-ORC evaluated in in Jackson, MS.
\end{abstract}

Keywords: solar ORC; regenerative ORC; Organic Rankine Cycle; primary energy consumption; carbon dioxide emissions

\section{Introduction}

Organic Rankine Cycles (ORCs) have become an area of increased interest and study because of their ability to use heat transfer from low to medium temperature sources to generate power. Various sources of heat can be used to power ORCs such as waste heat, geothermal energy, and solar energy [1-5]. ORCs typically generate small amounts of electricity, so they are ideal for small scale applications. The working fluid greatly affects the performance of ORCs, therefore fluid selection and performance has been widely studied by several researchers [6-11]. Rayegan and Tao [12] evaluated 34 fluids for several solar powered ORC configurations based on thermal efficiency, exergetic efficiency, vapor expansion ratio and network output. Mago et al. [13] modeled a regenerative ORC using four dry fluids and performed a first and second law analysis. They found that of the evaluated fluids, R113 had the highest thermal efficiency and that the regenerative cycle increased the thermal efficiency while decreasing the irreversibility.

Regenerative ORCs (R-ORC) have been studied for various applications as well [14-18]. Roy and Misra [19] evaluated a R-ORC using R134a and R123 as the working fluid for waste heat recovery. They found that for a turbine inlet pressure of $2.5 \mathrm{MPa}, \mathrm{R} 123$ performed better than R134a. 
Li et al. [20] studied an experimental R-ORC using geothermal heat as the heat source and R123 as the working fluid. They found that the R-ORC had a higher efficiency than a basic ORC cycle for the case they evaluated. In addition, they investigated the effect of mass flow rate on the system performance and found out that as the mass flow rate increased the turbine inlet pressure and turbine rotational speed increased while the regenerator efficiency decreased. Mago et al. [21] examined exergy destruction in basic and R-ORCs using the network topological methodology. It was found that the evaporator contributed the most to the exergy loss of both cycles, but the loss of exergy was reduced in the regenerative cycle. In a study by Imran et al. [22], the authors performed a thermo-economic analysis on a basic ORC, a single stage R-ORC, and a double stage R-ORC. They found that of the five fluids they investigated R245fa under the modeled conditions had the lowest specific investment cost, and the evaporator pressure had a significant impact on thermal efficiency and specific investment cost.

Primary energy consumption (PEC), carbon dioxide emissions (CDE), and economic analyses have been performed on power systems to determine their energy, environmental and economic viability. Fumo and Chamra [23] analyzed a combined cooling, heating, and power (CCHP) system to determine what conditions are needed to generate PEC savings. In another study by Mago et al. [24], combined heat and power (CHP) systems and CHP-ORC systems were evaluated for a small office building in six different cities in different climate zones and were compared to purchasing electricity from the grid while using a boiler to cover the thermal load of the facility. They reported that using a CHP-ORC resulted in PEC savings, CDE savings, and cost savings when compared to operating a $\mathrm{CHP}$ system alone. The savings from operating a CHP-ORC system when compared to the reference case depended on the location of the office building. Lecompte et al. [25] used an optimization strategy to minimize the specific investment cost of an ORC under fixed and part load conditions. They applied this strategy to a case study of a retail company utilizing waste heat from a CHP system to power the ORC. Calise et al. [26] studied off-design performance of an ORC. They modeled a solar powered ORC and performed a thermoeconomic analysis by optimizing the design parameters of the heat exchangers in the system. After the optimization was performed, the ORC performance under off design conditions was investigated by changing the heat source mass flow rate and temperature. They found that the heat source mass flow rate greatly affected the performance of the ORC. In a study by Quoilin et al. [27], an economic optimization as well as a thermodynamic optimization was performed for different working fluids for a waste heat recovery ORC. They found that the operating conditions were different for the working fluids when they optimized based on economic criteria versus thermodynamic criteria. Feng et al. [28] performed a thermodynamic and economic analysis to compare an ORC to a R-ORC with R123 as the working fluid. A non-dominated sorting genetic algorithm was used to find a set of optimum operating conditions when optimizing both exergy efficiency and levelized energy cost by varying the evaporator outlet temperature, condenser temperature, the degree of superheat, the degree of supercooling, and the pinch point temperature difference. The authors found that in order to maximize the exergy efficiency the levelized energy cost was at a maximum but in order to minimize the levelized energy cost then the exergy efficiency would be reduced for both a basic and regenerative cycle. They concluded that the Pareto-optimal solution was in between the maximum exergy efficiency operating conditions and the minimum levelized energy cost. They also found that while the regenerative cycle had a higher exergetic efficiency, it also had a higher levelized energy cost when compared to a basic ORC under a specific design and operating condition.

Several authors have studied solar powered ORCs [29-31]. Rayegan and Tao [32] modeled a solar powered R-ORC that provides electricity for a geothermal air conditioned net zero energy commercial building located in Pensacola (Florida, USA) using TRNSYS software. They evaluated 11 fluids and 3 types of solar collectors to determine the optimum combination under the modeled conditions. The authors found that the low temperature evacuated tube collectors using cyclohexane, isopentane, benzene, and R245ca as the working fluid provided the lowest solar collector areas necessary. Marion et al. [33] developed a theoretical model based on heat balance equations for a flat plate 
solar collector in line with an ORC and validated their proposed model with experimental results. They also performed a parametric study to optimize the system configuration and showed that the optimized configuration can produce net mechanical power with an efficiency up to $11 \%$. In another study by Wang et al. [34] a flat plate solar R-ORC was analyzed using R123, R245fa, $\mathrm{R} 134 \mathrm{a}$, and isobutane as working fluids. In addition, they used a thermal storage tank to prevent the fluctuations in heat supplied to the ORC from the solar collector and used a regenerator to transfer heat from the working fluid as it left the turbine to the working fluid before it enters the evaporator. Pei et al. [35] modeled a solar powered R-ORC using a two stage compound parabolic concentrator system with thermal storage using phase change materials. They used a two stage compound parabolic concentrator and evaporator system to heat the ORC working fluid first to a saturated liquid in the first stage and then vaporize the working fluid in the second stage. They found that the regenerator increased the efficiency of the ORC and slightly increased the overall system efficiency. The authors found the regenerator temperature had a significant effect on the solar collector efficiency as well as the ORC, i.e., as the regenerator temperature increased, the ORC efficiency increased, but the solar collector efficiency decreased.

In a previous study, Spayde and Mago [36] studied a basic solar powered ORC using five dry organic fluids in Jackson (Mississippi) and Tucson (Arizona). In their study, hourly solar irradiation values were obtained from ASHRAE by latitude for the 21st day of each month. They performed a parametric study to investigate the effect of temperature, pressure, solar collector area, and turbine efficiency on the overall system performance. The effect of producing electricity by the ORC versus purchasing electricity from the grid on PEC and CDE was also investigated as well as the available capital cost. They reported that R236ea performed the best of the evaluated fluids under the modeled conditions and generated the most PEC and CDE savings and available capital cost. For all the evaluated fluids, the system showed the best performance in the middle of the day. They also reported that increasing the solar collector area increased the net energy produced and total exergy destroyed whereas increasing solar collector pressure and condensing temperature decreased both the net energy generated and total exergy destroyed.

The present study expands the previous study by the authors by investigating the performance of a solar powered R-ORC using several dry working fluids, RC318, R227ea, R236ea, R236fa, and R218, in two different locations in the U.S. The results are compared with a solar powered basic ORC to establish the benefits of the proposed R-ORC. A thermo-economic analysis is performed to determine the fluid that provides the best performance under the modeled conditions for the evaluated fluids. In this study a flat plate solar collector is modeled as the evaporator of the R-ORC system. Because the flat plate collector is in line with the ORC, the irradiation collected from the flat plate collector, which is therefore available to the ORC, will vary with the local weather. The solar irradiation data is calculated hourly from local typical meteorological year 3 (TMY3) weather data available from National Renewable Energy Laboratory. A parametric analysis is also performed to study the effect of the turbine efficiency as well as the open feed organic fluid heater intermediate pressure on the system performance. In addition to the parametric analysis, the proposed system is evaluated in two locations because weather has a direct effect on the performance of the proposed R-ORC. Jackson, MS and Tucson, AZ were chosen because they have approximately the same latitude but are in different climate zones. The performance of the proposed R-ORC is analyzed based on the PEC and CDE savings, and the available capital cost for both locations.

\section{System Model}

This section describes the model used to evaluate the performance of the solar powered R-ORC. Figure 1 shows a schematic of the evaluated R-ORC and the associated T-s diagram. As can be seen in Figure 1, the system is a direct vapor generation (DVG), since the organic working fluid is directly heated to the vapor state at the evaporator [37]. 
The organic fluid at State 3 is pumped to State 4 and enters the flat plate solar collector where heat is transferred to the fluid. The organic working fluid at State 5 enters a two stage turbine, as a saturated vapor, where power is generated. In the first stage of the turbine, the fluid is expanded to State 6 , where a fraction of the organic fluid is extracted into an open feed organic fluid heater operating at the extraction pressure (Intermediate pressure). The remainder of the working fluid expands through the second stage of the turbine to State 7 and then passes through a condenser (State 1). This portion of the fluid is pumped to the intermediate pressure and introduced into the open feed organic fluid heater at State 2. For this model, this fluid is then mixed and heated with the fraction of the fluid that exits the first stage of the turbine so that the working fluid leaving the open feed organic fluid heater is a saturated liquid at the intermedia pressure. After the two fluid streams combine, the organic working fluid enters the second pump, at State 3, to increase the pressure before entering the solar collector at State 4 and repeating the cycle. Assumptions for this model include: a constant irradiation rate for each hour, a steady state system, no pressure losses, the intermediate pressure is the average of the high and low pressures for each working fluid, and constant isentropic efficiencies for the pumps and the turbine. In the model presented in this paper dry organic fluids are used since the saturated vapor curve has a negative slope which has been proven to provide improved results verses fluids that have a positive slope for the saturated vapor curve (wet fluids) [13].

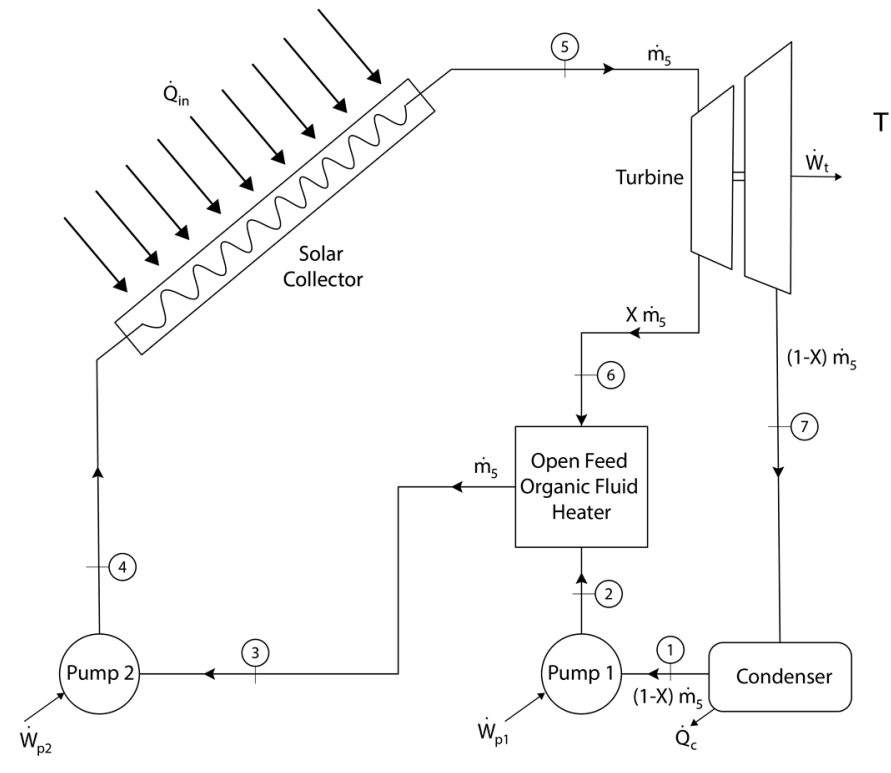

(a)

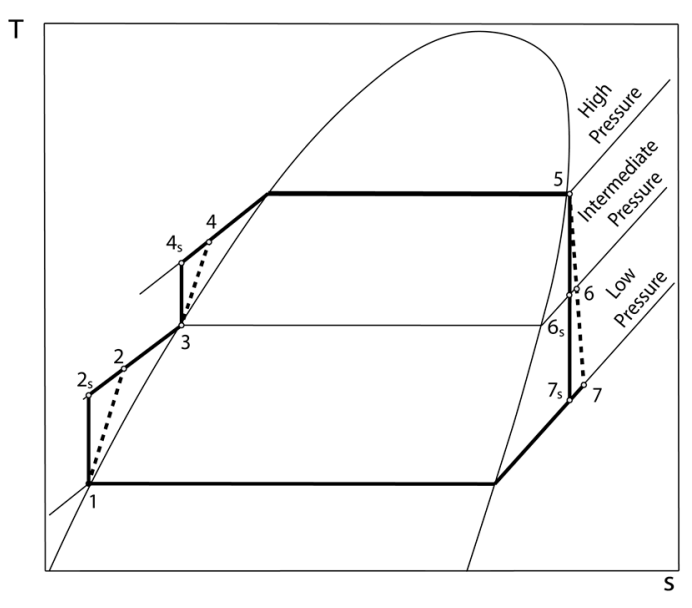

(b)

Figure 1. (a) Schematic of modeled solar powered R-ORC; (b) T-s diagram for the solar powered R-ORC.

a. Pump 1 (Process 1-2): The pump power can be determined as:

$$
\dot{W}_{p 1}=\frac{\dot{W}_{p 1 s}}{\eta_{p 1}}=\frac{\dot{m}_{5}(1-X)\left(h_{1}-h_{2 s}\right)}{\eta_{p 1}}=\dot{m}_{5}(1-X)\left(h_{1}-h_{2}\right)
$$

where $\dot{W}_{p 1 s}$ is the ideal power of Pump 1, $\eta_{p 1}$ is the isentropic efficiency of Pump 1, $\dot{m}_{5}$ is the mass flow rate of the working fluid at State $5, X$ is the fraction of the extracted fluid from the first stage of the turbine, and $h_{1}, h_{2 s}$, and $h_{2}$ are the enthalpy values of the working fluid at the pump inlet, the ideal enthalpy value at the pump exit, and the actual value at the pump exit, respectively. 
The exergy destruction rate for Pump 1 is:

$$
\Pi_{p 1}=\dot{E}_{p 1}-\left(\dot{E}_{2}-\dot{E}_{1}\right)
$$

where $\dot{E}_{p 1}$ is the pump exergy rate and $\dot{E}_{2}$ and $\dot{E}_{1}$ are the exergy rates for State 2 and State 1 , respectively.

The exergy rate of Pump 1 is given by:

$$
\dot{E}_{p 1}=\dot{W}_{p 1}
$$

The exergy rate change from State 1 to State 2 can be estimated as:

$$
\dot{E}_{2}-\dot{E}_{1}=\dot{m}_{5}(1-X)\left(h_{2}-h_{1}-T_{o}\left(s_{2}-s_{1}\right)\right)
$$

where $T_{0}, s_{1}$, and $s_{2}$ are the temperature at the dead state $(298 \mathrm{~K})$, and entropy values of the working fluid for States 1 and 2, respectively.

b. $\quad$ Pump 2 (Process 3-4): The power required for Pump 2 is given by

$$
\dot{W}_{p 2}=\frac{\dot{W}_{p 2 s}}{\eta_{p 2}}=\frac{\dot{m}_{5}\left(h_{3}-h_{4 s}\right)}{\eta_{p 2}}=\dot{m}_{5}\left(h_{3}-h_{4}\right)
$$

where $\dot{W}_{p 2 s}$ is the ideal power of Pump 2, $\eta_{p 2}$ is the isentropic efficiency of Pump 2, and $h_{3}$ and $h_{4}$ are the enthalpy values of the working fluid at State 3 and 4 , which are the inlet and outlet of Pump 2, respectively.

The exergy destruction rate for Pump 2 can be determined as:

$$
\Pi_{p 2}=\dot{E}_{p 2}-\left(\dot{E}_{4}-\dot{E}_{3}\right)
$$

where $\dot{E}_{p 2}$ is the exergy rate of Pump 2 and $\dot{E}_{4}$ and $\dot{E}_{3}$ are the exergy rates for State 4 and State 3 , respectively.

The exergy rate of Pump 2 is given by:

$$
\dot{E}_{p 2}=\dot{W}_{p 2}
$$

The change in exergy rate between States 4 and 3 is:

$$
\dot{E}_{4}-\dot{E}_{3}=\dot{m}_{5}\left(h_{4}-h_{3}-T_{0}\left(s_{4}-s_{3}\right)\right)
$$

where $s_{4}$ and $s_{3}$ are the entropy values of the working fluid at States 4 and 3, respectively.

c. Solar Collector (Process 4-5): This is an isobaric process where heat is supplied to the organic working fluid before the turbine inlet after the fluid exits the second pump. The flat plate solar collector replaces the evaporator in a typical R-ORC. The solar collector heat transfer rate into the working fluid follows:

$$
\dot{Q}_{i n}=\dot{m}_{5}\left(h_{5}-h_{4}\right)
$$

where $h_{5}$ is the enthalpy of the working fluid at the exit of the solar collector. 
The heat transfer rate from the solar collector can also be expressed as a function of irradiation:

$$
\dot{Q}_{\text {in }}=\eta_{\text {solar }} I A
$$

where $\eta_{\text {solar }}$ is the solar collector efficiency, $I$ is irradiation, and $A$ is the collector area.

The solar collector efficiency is determined using the relationship below:

$$
\eta_{\text {solar }}=y_{\text {int }}-m\left(\frac{T_{\text {in }}-T_{\text {amb }}}{I}\right)
$$

where $y_{\text {int }}$ is the $y$-intercept and $m$ is slope. These two terms are provided by the manufacturer or a third party certification. In the proposed model, $m=4.910 \mathrm{~W} / \mathrm{m}^{2} \cdot{ }^{\circ} \mathrm{C}$ and $y_{\text {int }}=0.706$ [38]. The equation for solar collector efficiency is the Hottel-Whiller-Bliss equation [39] where $y_{\text {int }}$ and $m$ correspond to:

$$
\begin{gathered}
y_{\text {int }}=F_{R} \tau \alpha \\
m=F_{R} U_{L}
\end{gathered}
$$

where $F_{R}$ is the collector heat removal factor, $\tau$ is the transmissivity of the glass cover plates, $\alpha$ is the absorptivity of the absorber plate, and $U_{L}$ is the losses due to conduction and radiation.

The irradiation values can be determined using the following equation:

$$
I_{t}=I_{D N} \cos \theta+I_{d H}\left(\frac{1+\cos \Sigma}{2}\right)+I_{t H} \rho\left(\frac{1-\cos \Sigma}{2}\right)
$$

where $I_{t}$ is the total irradiation, $I_{D N}$ is the direct normal irradiation, $\theta$ is the incidence angle, $I_{d H}$ is the diffuse horizontal irradiation, $\Sigma$ is the surface tilt angle, $I_{t H}$ is the total horizontal irradiation, and $\rho$ is the ground reflectance. Direct normal irradiation, diffuse horizontal irradiation, and total horizontal irradiation can be found in TMY3 data from the National Renewable Energy Laboratory [40]. The value for ground reflectance used in the paper is 0.2 which was taken from literature [41]. The incidence angle and surface tilt angle are dependent on the solar collector configuration (placement). In this study the solar collectors were modeled to be 2 axis tracking solar collectors. This gives the maximum solar irradiation. A two axis tracking system maintains the incidence angle at zero. The two axis tracking system leads to the following surface tilt equation:

$$
\Sigma=90-\beta
$$

where $\beta$ is the solar altitude which is given by [41]:

$$
\beta=\sin ^{-1}(\cos L \cos \delta \cos H+\sin L \sin \delta)
$$

where $L$ is latitude, $\delta$ is declination, and $H$ is the hour angle. Declination can be found by using the following equation [42]:

$$
\delta=23.45 \sin \left(360 \frac{284+n}{365}\right)
$$

where $n$ is the day of the year.

The exergy destruction rate of the solar collector is:

$$
\Pi_{s}=\dot{E}_{\dot{Q}_{s}}-\left(\dot{E}_{5}-\dot{E}_{4}\right)
$$


where $\dot{E}_{\dot{Q}_{s}}$ is the exergy rate due to the heat input to the solar collector and $\dot{E}_{5}$ is the exergy rate of State 5.

The change in exergy rate across the solar collector is found by:

$$
\dot{E}_{5}-\dot{E}_{4}=\dot{m}_{5}\left(h_{5}-h_{4}-T_{0}\left(s_{5}-s_{4}\right)\right)
$$

where $s_{5}$ is the entropy of the working fluid at the collector exit.

The exergy rate of the solar collector can be estimated as:

$$
\dot{E}_{\dot{Q}_{s}}=\dot{Q}_{i n}\left(1-\frac{1}{3}\left(T_{o} / T\right)^{4}-\frac{4}{3}\left(T_{o} / T\right)\right)
$$

where $T$ is the solar radiation temperature which is assumed to be $6000 \mathrm{~K}$ [43].

d. Turbine (Process 5-6, 7): The power of the two stage turbine is determined by:

$$
\dot{W}_{t}=\eta_{t} \dot{W}_{t s}=\eta_{t} \dot{m}_{5}\left(h_{5}-h_{7 s}+X\left(h_{7 s}-h_{6 s}\right)\right)=\dot{m}_{5}\left(h_{5}-h_{7}+X\left(h_{7}-h_{6}\right)\right)
$$

where $\dot{W}_{t s}$ is the power of the ideal turbine, $\eta_{t}$ is the turbine isentropic efficiency, $h_{6}$ and $h_{6 s}$ are the enthalpies of the working fluid for the exit of the first stage of the turbine for the real and ideal cases respectively, and $h_{7}$ and $h_{7 s}$ are the enthalpies of the working fluid of the outlet of the second stage of the turbine for the real and ideal cases, respectively.

The exergy destruction rate of the turbine is expressed as:

$$
\Pi_{t}=\dot{E}_{5}-\dot{E}_{6}-\dot{E}_{7}-\dot{E}_{t}
$$

where $\dot{E}_{t}$ is the exergy rate of the turbine and $\dot{E}_{6}$ and $\dot{E}_{7}$ are the exergy rates for State 6 and State 7 , respectively.

The change in exergy rates from the inlet to the outlets of the turbine is:

$$
\dot{E}_{5}-\dot{E}_{6}-\dot{E}_{7}=\dot{m}_{5}\left[\left(h_{5}-h_{7}\right)-X\left(h_{6}-h_{7}\right)-T_{o}\left(\left(s_{5}-s_{7}\right)-X\left(s_{6}-s_{7}\right)\right)\right]
$$

where $s_{6}$ and $s_{7}$ are the entropy values at State 6 and 7, respectively.

The turbine exergy rate is:

$$
\dot{E}_{t}=\dot{W}_{t}
$$

e. Open feed organic fluid heater (Process 6, 2-3): The extraction fraction is defined as:

$$
X=\frac{h_{3}-h_{2}}{h_{6}-h_{2}}=\frac{\dot{m}_{6}}{\dot{m}_{5}}
$$

where $\dot{m}_{6}$ is the mass flow rate of the working fluid at the exit of the first stage of the turbine.

The open feed organic fluid heater exergy destruction rate is determined by:

$$
\Pi_{f}=\dot{E}_{6}+\dot{E}_{2}-\dot{E}_{3}
$$

The exergy balance is:

$$
\dot{E}_{6}+\dot{E}_{2}-\dot{E}_{3}=\dot{m}_{5}\left[\left(h_{2}-h_{3}\right)-X\left(h_{2}-h_{6}\right)-T_{o}\left(\left(s_{2}-s_{3}\right)-X\left(s_{2}-s_{6}\right)\right)\right]
$$


f. Condenser (Process 7-1): The heat transfer rate leaving the condenser follows:

$$
\dot{Q}_{c}=(1-X) \dot{m}_{5}\left(h_{1}-h_{7}\right)
$$

The exergy destruction rate of the condenser is:

$$
\Pi_{c}=\dot{E}_{7}-\dot{E}_{1}-\dot{E}_{\dot{Q}_{c}}
$$

where $\dot{E}_{\dot{Q}_{c}}$ is the exergy rate of the condenser.

The exergy balance across the condenser is given by:

$$
\dot{E}_{7}-\dot{E}_{1}=\dot{m}_{5}(1-X)\left(h_{7}-h_{1}-T_{o}\left(s_{7}-s_{1}\right)\right)
$$

The exergy rate of the condenser is given by the following equation:

$$
\dot{E}_{\dot{Q}_{c}}=\dot{Q}_{c}\left(1-\frac{T_{0}}{T_{L}}\right)
$$

where $T_{L}$ is the low temperature heat sink which is assumed to be $303 \mathrm{~K}$.

g. R-ORC Net Power: The equation for the net power of the R-ORC is:

$$
\dot{W}_{n e t}=\dot{W}_{t}-\dot{W}_{p 1}-\dot{W}_{p 2}
$$

h. R-ORC Efficiencies: The R-ORC thermal efficiency and R-ORC exergetic efficiency can be expressed as:

$$
\begin{gathered}
\eta_{I}=\frac{\dot{W}_{n e t}}{\dot{Q}_{i n}}=\frac{\left(h_{5}-h_{7}+X\left(h_{7}-h_{6}\right)\right)-(1-X)\left(h_{2}-h_{1}\right)-\left(h_{4}-h_{3}\right)}{\left(h_{5}-h_{4}\right)} \\
\eta_{I I}=\frac{\dot{E}_{\dot{W}_{\text {net }}}}{\dot{E}_{\dot{Q}_{\text {in }}}}=\frac{\left(h_{5}-h_{7}+X\left(h_{7}-h_{6}\right)\right)-(1-X)\left(h_{2}-h_{1}\right)-\left(h_{4}-h_{3}\right)}{\left(h_{5}-h_{4}\right)\left(1-\frac{1}{3}\left(\frac{T_{o}}{T}\right)^{4}-\frac{4}{3}\left(\frac{T_{o}}{T}\right)\right)}
\end{gathered}
$$

where $\dot{E}_{\dot{W}_{\text {net }}}$ and $\dot{E}_{\dot{Q}_{i n}}$ are the exergy of the products and the exergy input to the ORC. $\dot{E}_{\dot{W}_{\text {net }}}$ can be estimated as:

$$
\dot{E}_{\dot{W}_{n e t}}=\dot{W}_{n e t}
$$

i. R-ORC Component Exergetic Efficiencies: The exergetic efficiency of each component of the R-ORC can be found by defining exergetic efficiency as the used exergy divided by the available exergy for each component. Equations (36) through (41) define each component's exergetic efficiency:

$$
\begin{gathered}
\eta_{x, p 1}=\frac{\dot{E}_{2}-\dot{E}_{1}}{\dot{E}_{p 1}} \\
\eta_{x, p 2}=\frac{\dot{E}_{4}-\dot{E}_{3}}{\dot{E}_{p 2}} \\
\eta_{x, s}=\frac{\dot{E}_{5}-\dot{E}_{4}}{\dot{E}_{\dot{Q}_{i n}}}
\end{gathered}
$$




$$
\begin{gathered}
\eta_{x, t}=\frac{\dot{E}_{t}}{\dot{E}_{5}-\dot{E}_{6}-\dot{E}_{7}} \\
\eta_{x, f}=\frac{\dot{E}_{3}}{\dot{E}_{2}+\dot{E}_{6}} \\
\eta_{x, c}=\frac{\dot{E}_{\dot{Q}_{c}}}{\dot{E}_{7}-\dot{E}_{1}}
\end{gathered}
$$

The contribution of each component to the total exergy destruction rate of the R-ORC can be estimated as:

$$
\% \Pi_{i}=\frac{\Pi_{i}}{\Pi_{\text {total }}}
$$

where $\Pi_{i}$ represents the exergy destruction for each component and $\Pi_{\text {total }}$ is the total exergy destruction rate of the R-ORC system:

$$
\Pi_{\text {total }}=\Pi_{p 1}+\Pi_{p 2}+\Pi_{s}+\Pi_{t}+\Pi_{f}+\Pi_{c}
$$

j. $\quad$ Primary Energy Consumption (PEC) Savings: Generating electricity on site using solar energy instead of purchasing electricity from the grid results in PEC savings and can be estimated by subtracting the PEC from the R-ORC $\left(P E C_{R-O R C}\right)$ from the PEC from the conventional system $\left(P E C_{\text {Conv }}\right)$ as follows:

$$
P E C_{\text {savings }}=P E C_{C o n v}-P E C_{R-O R C}=\dot{W}_{\text {net }} \times E C F_{P E C}-\dot{W}_{\text {net }} \times S C F_{P E C}
$$

where $P E C_{\text {savings }}$ is the PEC savings, $E C F_{P E C}$ is the site-to-source conversion factor for electricity (grid purchase), which varies depending on location [23,44], and $S C F_{P E C}$ is the site-to-source conversion factor for electricity (solar), which was chosen to have a value of $1[45,46]$.

k. Carbon Dioxide Emission (CDE) Savings: Since the R-ORC utilizes solar energy, there are no $\mathrm{CDE}$ associated with the electricity generation. This results in CDE savings when compared to purchasing electricity from the grid. The CDE savings can be found by subtracting the CDE from the R-ORC $\left(C D E_{R-O R C}=0\right)$ from the $C D E$ from the conventional system $\left(C D E_{C o n v}\right)$ as follows:

$$
C D E_{\text {reduction }}=C D E_{\text {conv }}-C D E_{R-O R C}=\dot{W}_{\text {net }} \times E C F_{C D E}
$$

where $C D E_{\text {reduction }}$ is the $C D E$ savings and $E C F_{C D E}$ is the carbon dioxide emissions factor for electricity which is location dependent [47].

l. Cost Savings and Available Capital Cost: Available yearly capital cost (ACC) is a means to determine the maximum capital cost for a given payback period based on the cost of purchased electricity from the grid. It is based on the purchased electricity savings that result from using the solar powered R-ORC to generate electricity. The available capital cost can indicate the feasibility of implementing a solar powered ORC for a specific location. The following equation determines the cost savings and maximum capital cost available depending on the desired payback period:

$$
\begin{gathered}
\text { Cost }_{\text {savings }}=\dot{W}_{\text {net }} \times \text { Cost }_{e} \\
A C C=\sum_{P B P} \text { Cost }_{\text {savings }}
\end{gathered}
$$

where $\operatorname{Cost}_{e}$ is the yearly forecasted cost of electricity and $P B P$ is the desired payback period. The cost of electricity is forecasted by plotting the average retail price of residential electricity 
from 2004 to 2015 [48] and performing a linear regression to estimate the future average retail price.

\section{Results and Discussion}

The model described in Section 2 was employed to simulate an hourly solar powered R-ORC in Jackson, MS and Tucson, AZ. The solar collector was modeled as a two axis tracking collector, so that the maximum irradiation values would be used. The hourly irradiation and ambient temperature data that was used to determine the solar collector efficiency and the heat transferred from the solar collector was found from TMY3 data for both locations selected for this study. Jackson and Tucson were chosen because they are at approximately the same latitude but are in different climate zones. Figure 2 depicts the yearly irradiation data used for both Jackson, MS and Tucson, AZ calculated from TMY3 weather data. Figure 2 illustrates that Tucson receives more irradiation than Jackson throughout the year. Tucson also had in general higher ambient temperatures which affected the solar collector efficiency.

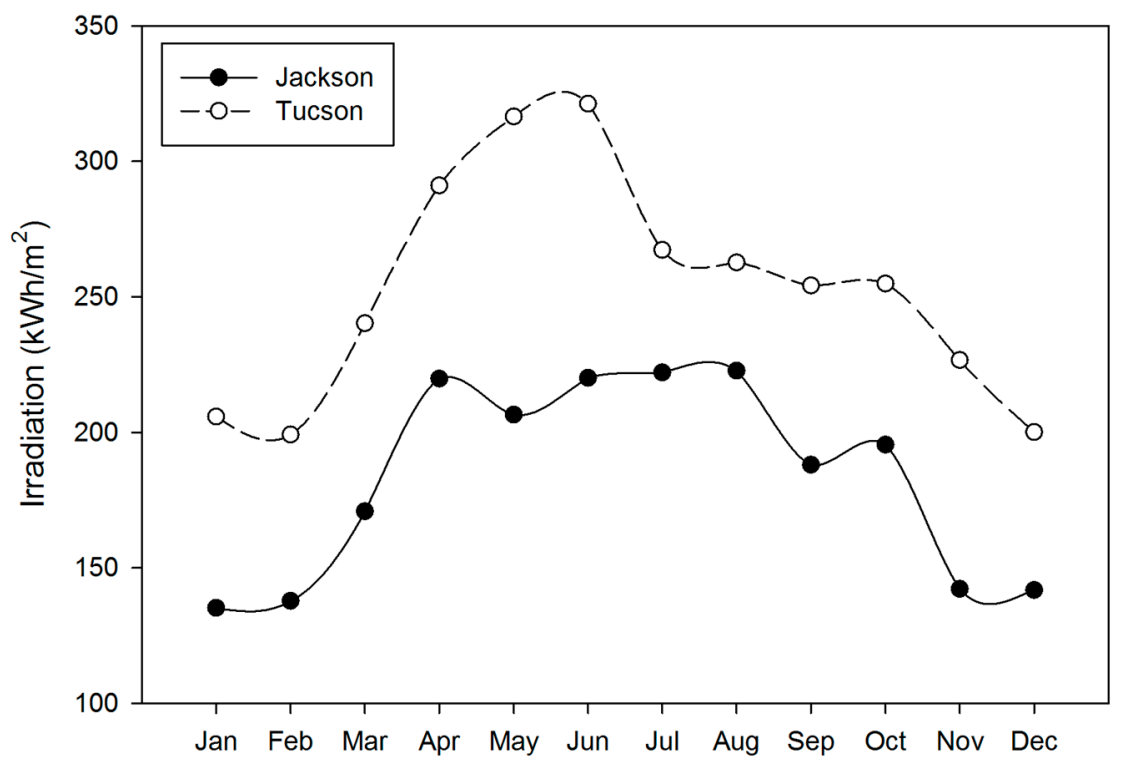

Figure 2. Yearly irradiation data for Jackson, MS and Tucson, AZ calculated from TMY3 weather data [40].

Five dry organic working fluids were used in this paper: R236ea, R236fa, RC318, R227ea, and R218. As mentioned before, in this study, the state of the working fluid was assumed to be fixed as a saturated vapor as the fluid leaves the solar collector; therefore, the maximum available energy from the solar collector was harvested by changing the mass flow rate of the working fluid. Thus the changing irradiation values and ambient temperatures affected the amount of power generated by the R-ORC. In addition, for each of the selected fluids, the fluid enters both pumps were assumed to be saturated liquid. For all fluids, the condensing temperature was assumed to be $30{ }^{\circ} \mathrm{C}$, the solar collector pressure was $2 \mathrm{MPa}$, and the pressure of the open feed organic fluid heater was set as the average pressure between the solar collector and the condenser. The pump and turbine isentropic efficiencies were assumed to be $80 \%$. Since the mass flow rate of the organic working fluid changes depending on the amount of irradiation from the solar collector, the efficiencies of the pump and turbine will vary during the process, however, they were assumed constant to simplify the proposed model. To account for this, the effect of turbine efficiency on the net energy produced and the total exergy destroyed is investigated in a parametric study presented later in this paper. The pressure and temperature ranges for each fluid are given in Table 1 [49]. 
Table 1. Critical pressure [49] and pressure and temperature ranges for each of the evaluated fluids.

\begin{tabular}{ccccccc}
\hline Fluid & $\begin{array}{c}\text { Critical } \\
\text { Pressure } \\
(\mathbf{M P a})\end{array}$ & $\begin{array}{c}\text { Low } \\
\text { Pressure } \\
\mathbf{( M P a )}\end{array}$ & $\begin{array}{c}\text { Low } \\
\text { Temperature } \\
\left({ }^{\circ} \mathbf{C}\right)\end{array}$ & $\begin{array}{c}\text { Intermediate } \\
\text { Pressure } \\
\mathbf{( M P a )}\end{array}$ & $\begin{array}{c}\text { High } \\
\text { Pressure } \\
(\mathbf{M P a})\end{array}$ & $\begin{array}{c}\text { High } \\
\text { Temperature } \\
\left({ }^{\circ} \mathbf{C}\right)\end{array}$ \\
\hline RC318 & 2.7775 & 0.36556 & 30 & 1.18278 & 2 & 98.75 \\
R236fa & 3.2 & 0.32101 & 30 & 1.160505 & 2 & 101.47 \\
R236ea & 3.502 & 0.24437 & 30 & 1.122185 & 2 & 111.65 \\
R227ea & 2.926 & 0.52866 & 30 & 1.26433 & 2 & 83.423 \\
R218 & 2.671 & 0.99165 & 30 & 1.495825 & 2 & 59.094 \\
\hline
\end{tabular}

\subsection{System Performance}

The R-ORC was compared with a basic ORC using the same irradiation data and locations for each of the five evaluated fluids. Table 2 presents the thermal and exergetic efficiencies for each fluid for both the R-ORC and basic ORC. For all of the evaluated fluids, the R-ORC had higher thermal and exergetic efficiencies than the basic ORC when both systems operated using the same working fluid. In Table 3, the net energy generated and total exergy destroyed are presented for the five fluids in both the R-ORC and basic ORC. The R-ORC model was able to generate more net energy and had less total exergy destruction than the modeled basic ORC for each of the evaluated fluids. Among all the evaluated fluids, R236ea performed the best under the modeled conditions for both the $\mathrm{R}-\mathrm{ORC}$ and basic ORC with respect to the thermal and exergetic efficiencies, the net energy produced, and the total exergy destroyed. To study the performance of the proposed solar R-ORC, the system was evaluated using four collectors with an area of $3.696 \mathrm{~m}^{2}$ each. Under the modeled conditions, the R-ORC using R236ea as the working fluid produced $2852 \mathrm{kWh} /$ year in Jackson, MS. The R-ORC using R236fa as the working fluid had slightly higher efficiencies, higher net energy produced, and lower total exergy destroyed than the basic ORC with R236ea as the working fluid. Whereas the remaining fluids performed worse than R236ea in the basic ORC regardless of the chosen cycle under the modeled conditions. RC318 had the largest percent increase, $13.27 \%$, of net energy produced per year, and R236ea had the largest percent decrease, $1.84 \%$, of total exergy destruction per year when comparing the R-ORC to the basic ORC.

Table 2. Thermal and exergetic efficiencies for each of the evaluated fluids in both the basic ORC and R-ORC.

\begin{tabular}{ccccc}
\hline & \multicolumn{2}{c}{ Thermal Efficiency } & \multicolumn{2}{c}{ Exergy Efficiency } \\
\hline Fluid & Basic ORC & R-ORC & Basic ORC & R-ORC \\
\hline RC318 & 10.10 & 11.44 & 10.82 & 12.25 \\
R236fa & 11.16 & 12.50 & 11.95 & 13.39 \\
R236ea & 12.40 & 13.89 & 13.28 & 14.87 \\
R227ea & 8.81 & 9.86 & 9.44 & 10.56 \\
R218 & 5.16 & 5.65 & 5.53 & 6.05 \\
\hline
\end{tabular}

Table 3. The net energy produced and total exergy destroyed for each of the evaluated fluids for the basic ORC and R-ORC.

\begin{tabular}{ccccccc}
\hline & \multicolumn{2}{c}{ Net Energy Produced $\mathbf{~ ( k W h / Y e a r ) ~}$} & \multicolumn{2}{c}{ Total Exergy Destroyed (kWh/Year) } \\
\hline Fluid & Basic ORC & R-ORC & \% Increase & Basic ORC & R-ORC & \% Decrease \\
\hline RC318 & 2074 & 2349 & 13.27 & 16,796 & 16,525 & 1.61 \\
R236fa & 2291 & 2567 & 12.07 & 16,583 & 16,311 & 1.64 \\
R236ea & 2546 & 2852 & 12.01 & 16,331 & 16,031 & 1.84 \\
R227ea & 1809 & 2024 & 11.88 & 17,056 & 16,845 & 1.24 \\
R218 & 1060 & 1160 & 9.42 & 17,794 & 17,695 & 0.55 \\
\hline
\end{tabular}


Table 4 shows the percent contribution to the total exergy destruction rate for each of the components in the R-ORC for each of the evaluated fluids. The solar collector had the highest percentage contribution to the exergy destruction rate for all of the evaluated fluids. R236ea had the lowest percentage contribution for the solar collector among the evaluated fluids with a value of $91.76 \%$. The turbine had the next highest percent contribution to the total exergy destruction rate with a range of $4.22 \%$ to $1.95 \%$ for the evaluated fluids. R236ea had the highest percent contribution for the turbine at $4.22 \%$. The open feed organic fluid heater was the third largest contributor to the total exergy destruction rate with a percentage range of $3.12 \%$ to $0.67 \%$ for the evaluated fluids. Again R236ea had the highest percent contribution for the open feed organic fluid heater among the evaluated fluids.

Since R236ea performed the best of the evaluated fluids under the modeled conditions, it is used as the organic working fluid for the remainder results presented in this paper. Figures 3 and 4 compare the basic ORC versus the R-ORC over the course of a year in Jackson, MS. The R-ORC produced more net energy and slightly less total exergy destruction per month than the basic ORC. The R236ea R-ORC produced $2852 \mathrm{kWh}$ /year of net energy and destroyed 16,301 kWh/year of exergy while the R236ea basic ORC generated $2546 \mathrm{kWh}$ /year of net energy and destroyed 16,331 kWh/year of exergy resulting in a $12.01 \%$ increase of net energy production and a $1.84 \%$ reduction of total exergy destruction.

Furthermore, the R-ORC was evaluated in Tucson, AZ and the results compared with those presented in Figures 3 and 4 for Jackson, MS. In Figure 5, the net energy produced and total exergy destroyed are compared for Jackson and Tucson. Since there was more solar irradiation in Tucson, the net energy produced and total exergy destruction was higher in Tucson when compared to Jackson. The increase in both net energy production and total exergy destruction was more pronounced in the summer months. The net energy generated per year for Tucson, AZ was $4162 \mathrm{kWh} /$ year which was $46 \%$ increase from the net energy produced in Jackson, MS.

Table 4. Percentage of contribution for each device to the total exergy destruction rate for the R-ORC.

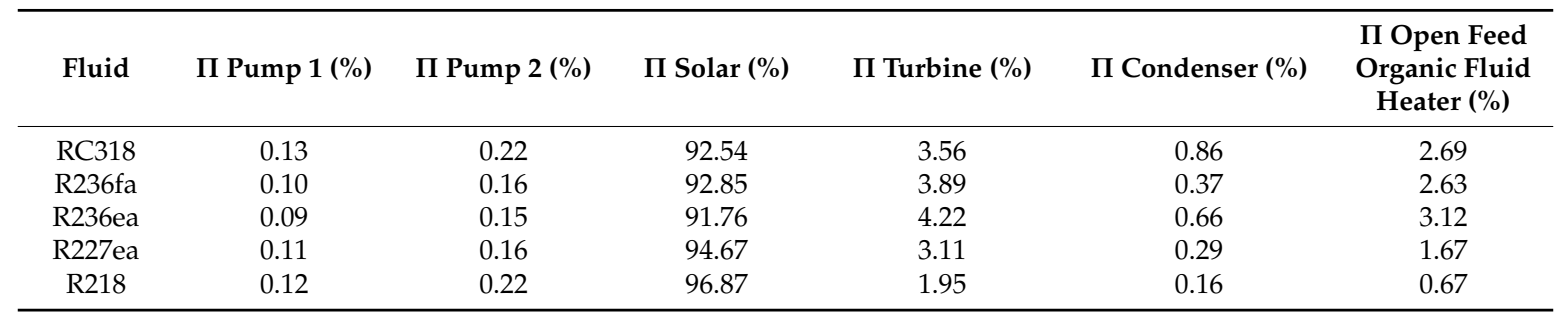

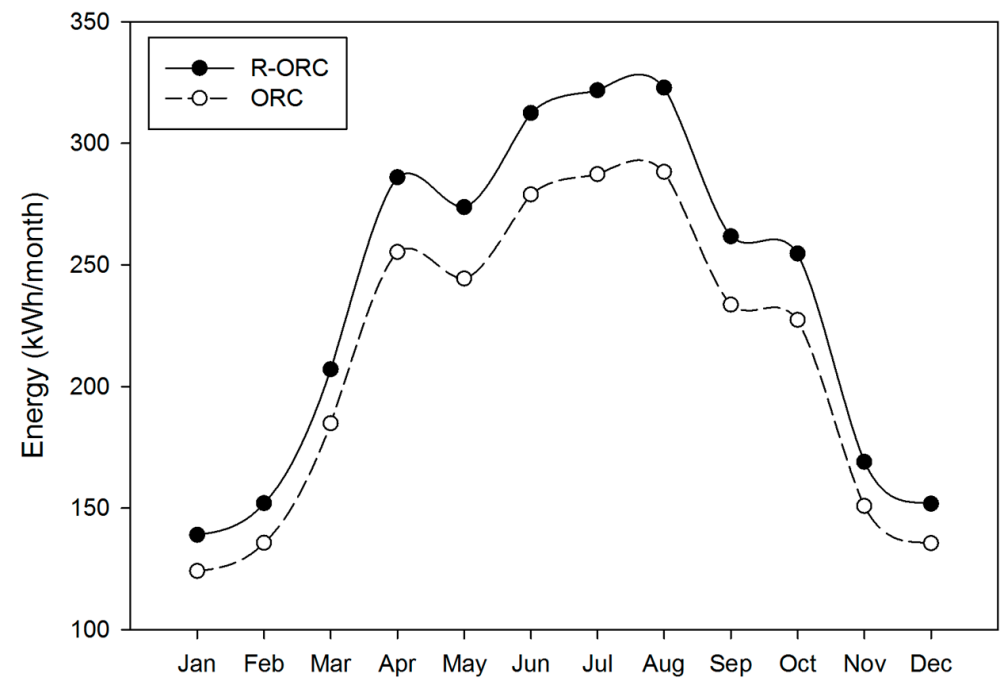

Figure 3. Net energy produced per month in Jackson, MS for the basic ORC and R-ORC configurations using R236ea as the working fluid. 


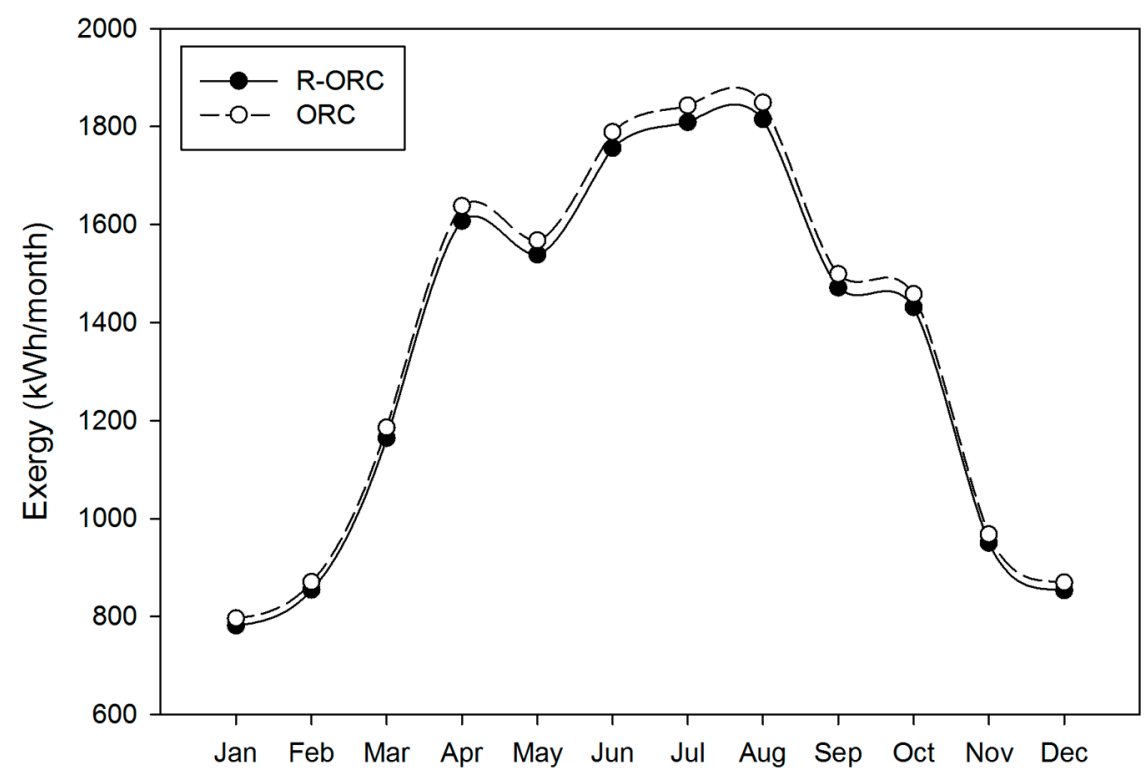

Figure 4. Total exergy destroyed per month in Jackson, MS for the basic ORC and R-ORC using R236ea as the working fluid.

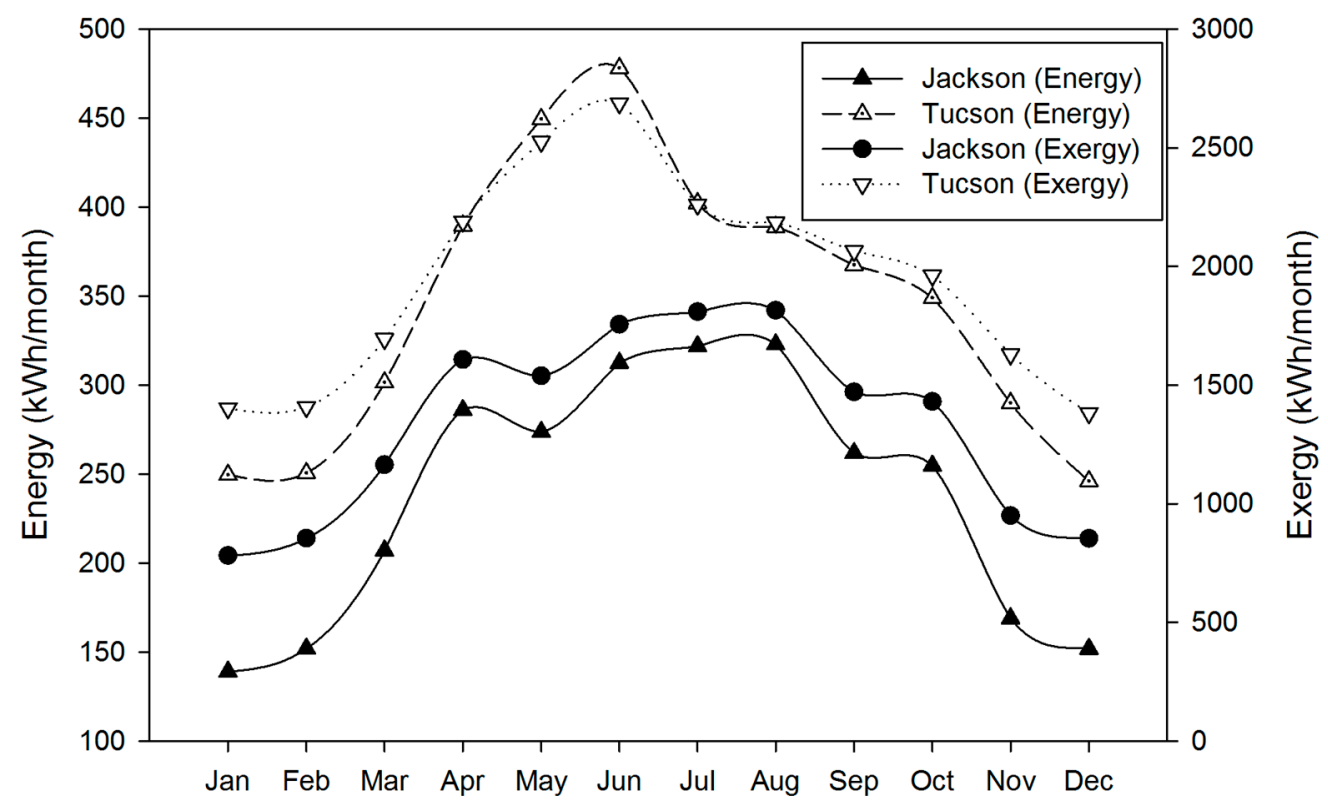

Figure 5. Net energy produced and total exergy destroyed in Jackson, MS and Tucson, AZ by the R-ORC using R236ea as the working fluid.

\subsection{Primary Energy Consumption and Carbon Dioxide Emissions}

The effect of replacing electricity purchased from the grid with electricity generated using solar power on the PEC and CDE was also investigated. Producing electricity from solar power has the potential for PEC and CDE savings as compared to purchasing electricity form the utility grid. Table 5 presents the site-to-source conversion factor for electricity (grid purchase) for Jackson, MS and Tucson, $\mathrm{AZ}$, the site-to-source conversion factor for electricity (solar), and the carbon dioxide emissions factor for electricity for both locations. 
Table 5. Site-to-source conversion factor for electricity and carbon dioxide emissions factor for electricity.

\begin{tabular}{cc}
\hline $\mathrm{ECF}_{P E C}$ (Jackson, MS) [44] & $3.14 \mathrm{kWh} / \mathrm{kWh}$ \\
$\mathrm{ECF}_{P E C}$ (Tucson, AZ) [44] & $3.06 \mathrm{kWh} / \mathrm{kWh}$ \\
SCF & $1 \mathrm{kWh} / \mathrm{kWh}$ \\
$\mathrm{ECF}_{C D E}$ (Jackson, MS) [47] & $0.467 \mathrm{~kg} / \mathrm{kWh}$ \\
$\mathrm{ECF}_{C D E}$ (Tucson, AZ) [47] & $0.534 \mathrm{~kg} / \mathrm{kWh}$ \\
\hline
\end{tabular}

Figure 6 presents the PEC savings for both the R-ORC and basic ORC in Jackson, MS and Tucson, AZ. The PEC savings were higher in Tucson, AZ regardless of which cycle is used than Jackson, MS even though the ECF $F_{P E C}$ was slightly higher in Jackson. The higher savings in Tucson can be contributed from the higher amount of net energy produced by the ORC due to the increased solar irradiation available and the decreased amount of electricity purchased from the grid. The R-ORC produced more PEC savings than the basic ORC for each location because there was an increase in electricity produced in the R-ORC compared to the basic ORC. The yearly PEC savings for the R-ORC in Jackson and Tucson were $6104 \mathrm{kWh} /$ year and $8574 \mathrm{kWh} /$ year, respectively.

Implementing a solar powered R-ORC has also the potential of reducing the CDE since the R-ORC emits practically zero CDE. Figure 7 presents the CDE savings for the basic ORC and R-ORC in Jackson and Tucson. As with the PEC savings, the possible CDE savings were higher in Tucson, $\mathrm{AZ}$ versus Jackson, MS. The R-ORC also produced more potential CDE savings than the basic ORC. The possible yearly CDE savings for the R-ORC in Jackson and Tucson were $1332 \mathrm{~kg} /$ year and 2224 $\mathrm{kg} /$ year, respectively. The reason that more CDE savings are obtained in Tucson, AZ is that the carbon dioxide emission factor for electricity are higher in this location and emissions which indicates that higher carbon content is present in the flue mix used to generate electricity in that area.

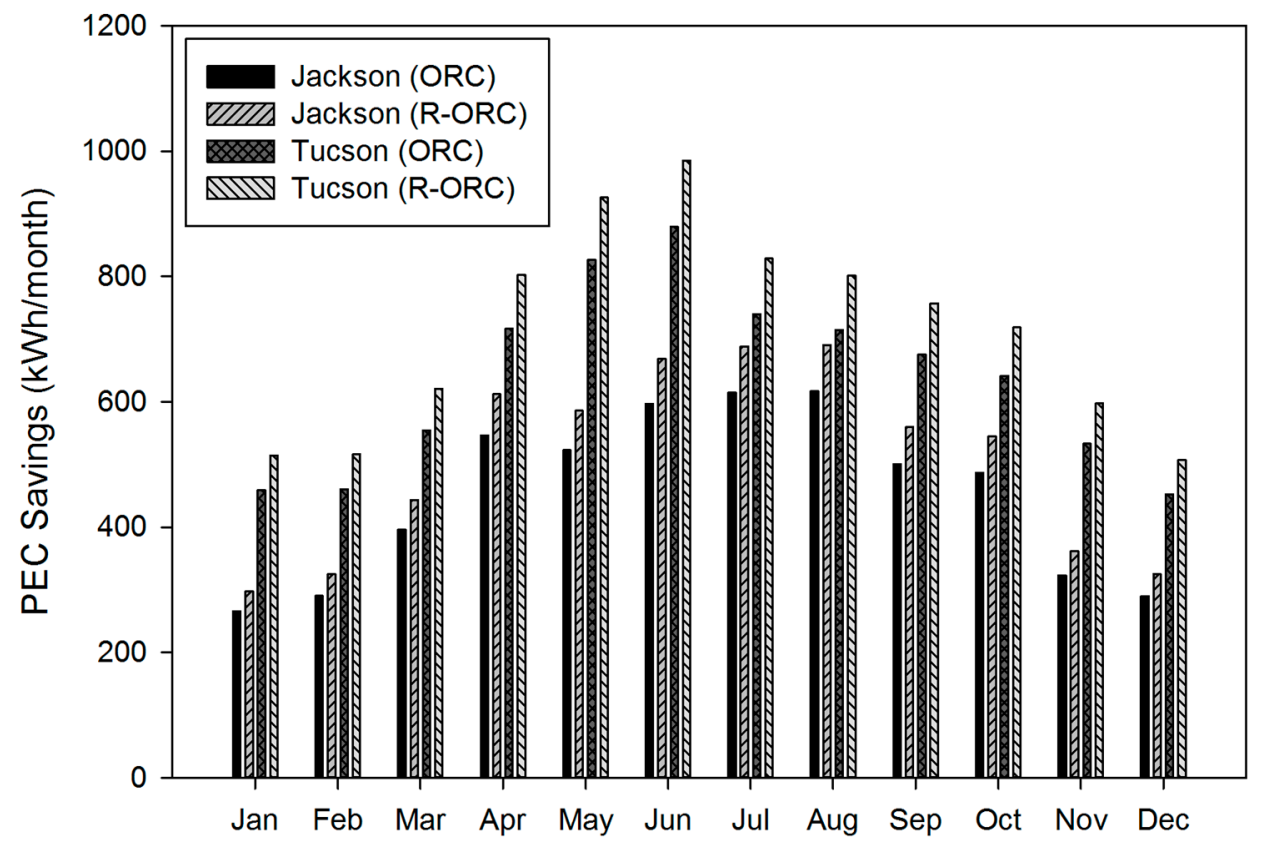

Figure 6. PEC savings from the basic ORC and R-ORC in Jackson, MS and Tucson, AZ using R236ea as the working fluid. 


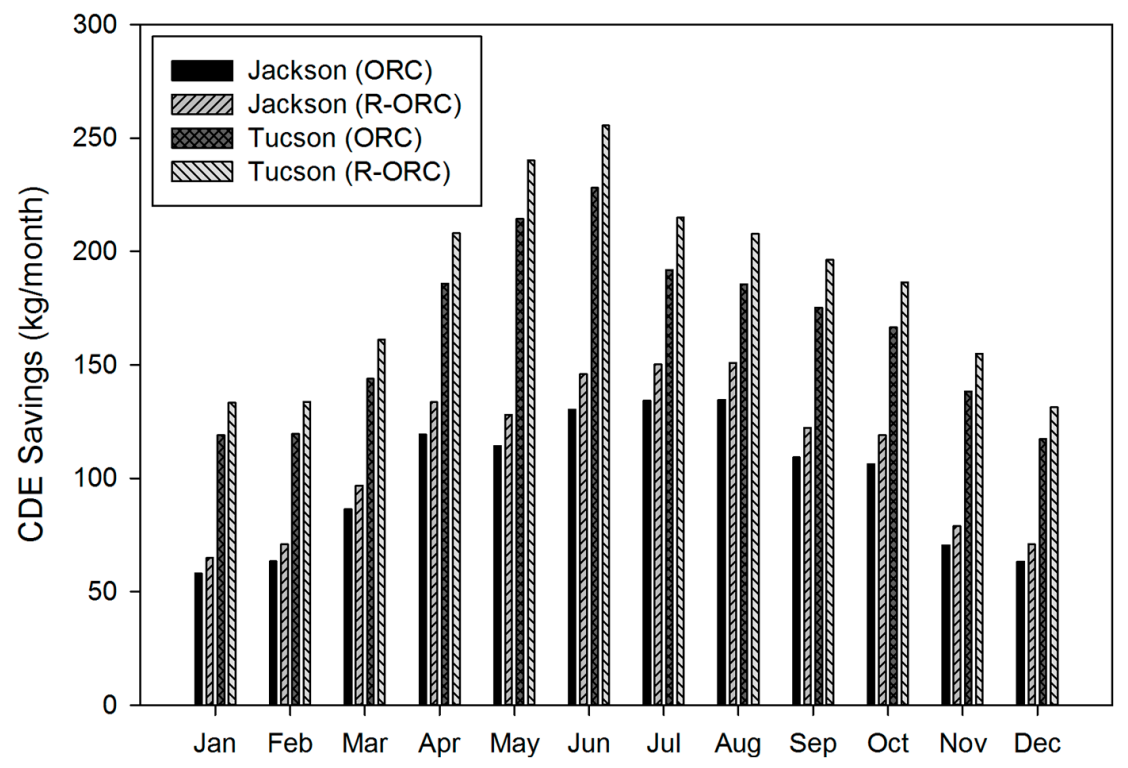

Figure 7. CDE savings from the basic ORC and R-ORC in Jackson, MS and Tucson, AZ using R236ea as the working fluid.

\subsection{Available Capital Cost}

Available Capital Cost (ACC) determines the maximum capital cost for a given payback period based on the cost saving potential from grid electricity price. The ACC for the proposed system is shown in Figure 8 for a payback period ranging from 1 to 10 years. The ACC values were determined based on the current and forecasted national average purchased electricity cost until 2025. The predicted national average for 2016 is $0.13 \$ / \mathrm{kWh}$ and for 2025 is $0.16 \$ / \mathrm{kWh}$. Applying these predicted electricity costs resulted in ACCs of $\$ 4198$ for Jackson, MS and $\$ 6127$ for Tucson, AZ given a 10 year payback period. Tucson had a higher ACC because the modeled R-ORC produced more electricity in Tucson than in Jackson. This indicates that for the R-ORC to have a payback period of less than 10 years in Tucson the capital cost must be less than $\$ 6127$ based on an increasing national average electricity purchase price.

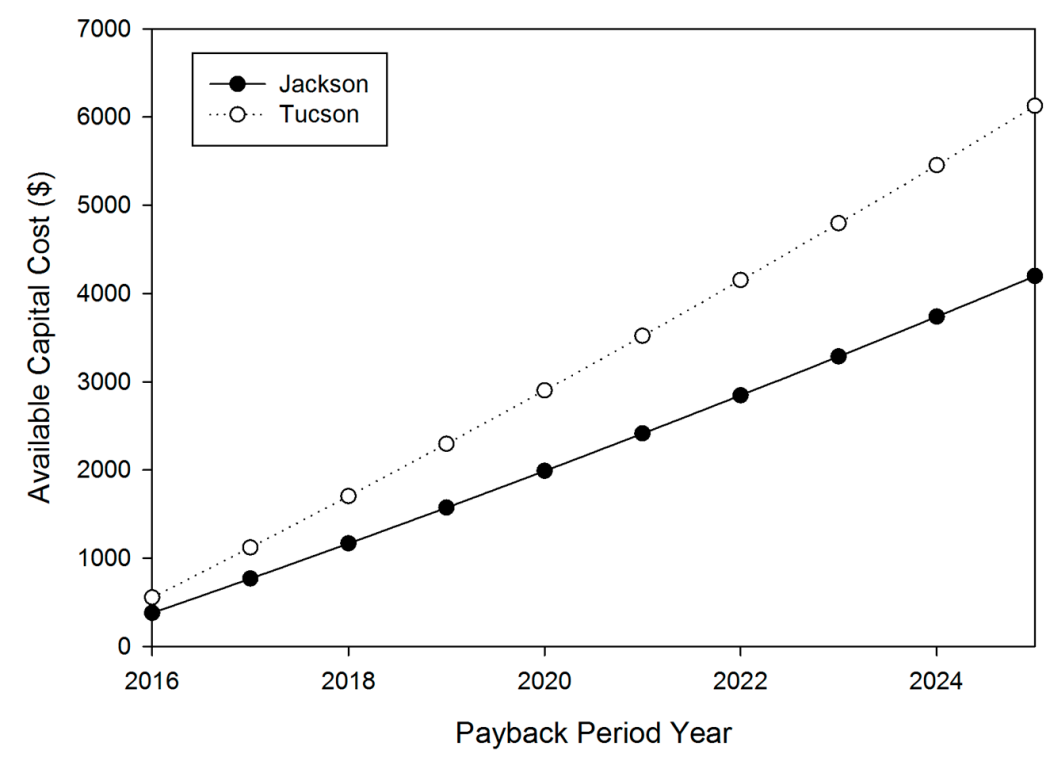

Figure 8. Available capital cost for Jackson, MS and Tucson, AZ for a payback period of up to ten years using a forecasted national average electricity price using R236ea as the working fluid. 


\subsection{Parametric Analysis}

The effect of the intermediate pressure (extraction pressure) and the turbine efficiency on the net energy produced, the total exergy destroyed, and the system mass flow rate was investigated. Figure 9 shows the effect of the intermediate pressure on the net energy produced, total exergy destroyed, and the average mass flow rate for the months of January and July when the intermediate pressure varies from $0.3 \mathrm{MPa}$ to $1.9 \mathrm{MPa}$. The net energy produced, total exergy destroyed, and average mass flow rate were higher in the month of July compared to those in January. The average mass flow rates for both January and July increased as the intermediate pressure increased. The maximum net energy produced and the minimum exergy destroyed occurred at the same intermediate pressure value of $0.75 \mathrm{MPa}$. Changing the turbine efficiency only affected the net energy produced and the total exergy destroyed. The effect of the turbine efficiency on the net energy produced and the total exergy destroyed for the months of January and July is displayed in Figure 10. The efficiency of the turbine was varied from $50 \%$ to $80 \%$. As the turbine efficiency increased, the net energy increased and the total exergy destroyed decreased slightly. The percent increase of net energy produced did not change for the months of January and July. Likewise, the percent decrease of the total exergy destroyed did not change for January and July. As the turbine efficiency increased from $70 \%$ to $80 \%$, the percent increase of net energy produced was $15 \%$, and the percent decrease of exergy destruction was $2.2 \%$.

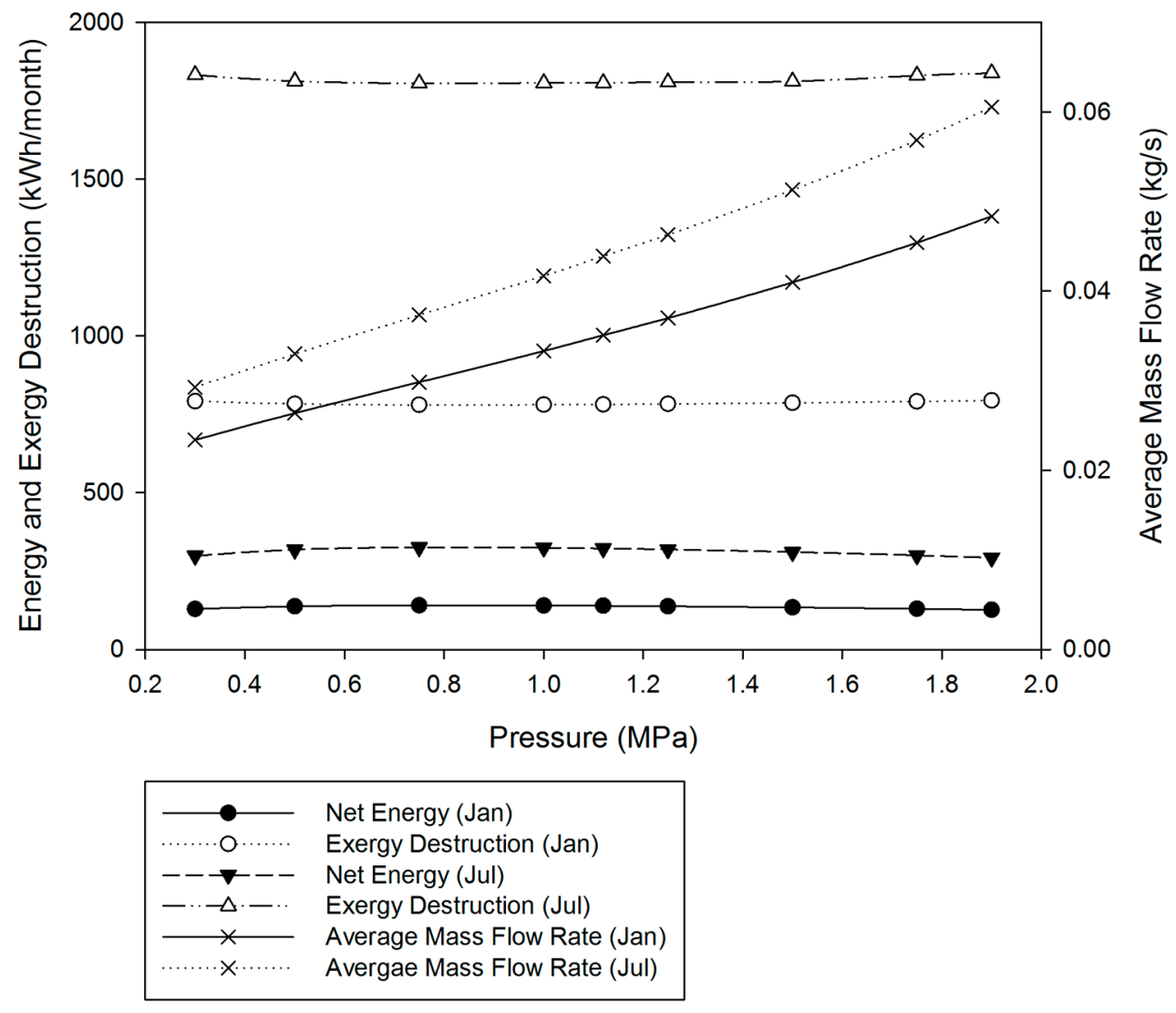

Figure 9. The effect of intermediate pressure on the net energy produced, total exergy destroyed, and average mass flow rate for January and July in Jackson, MS. 


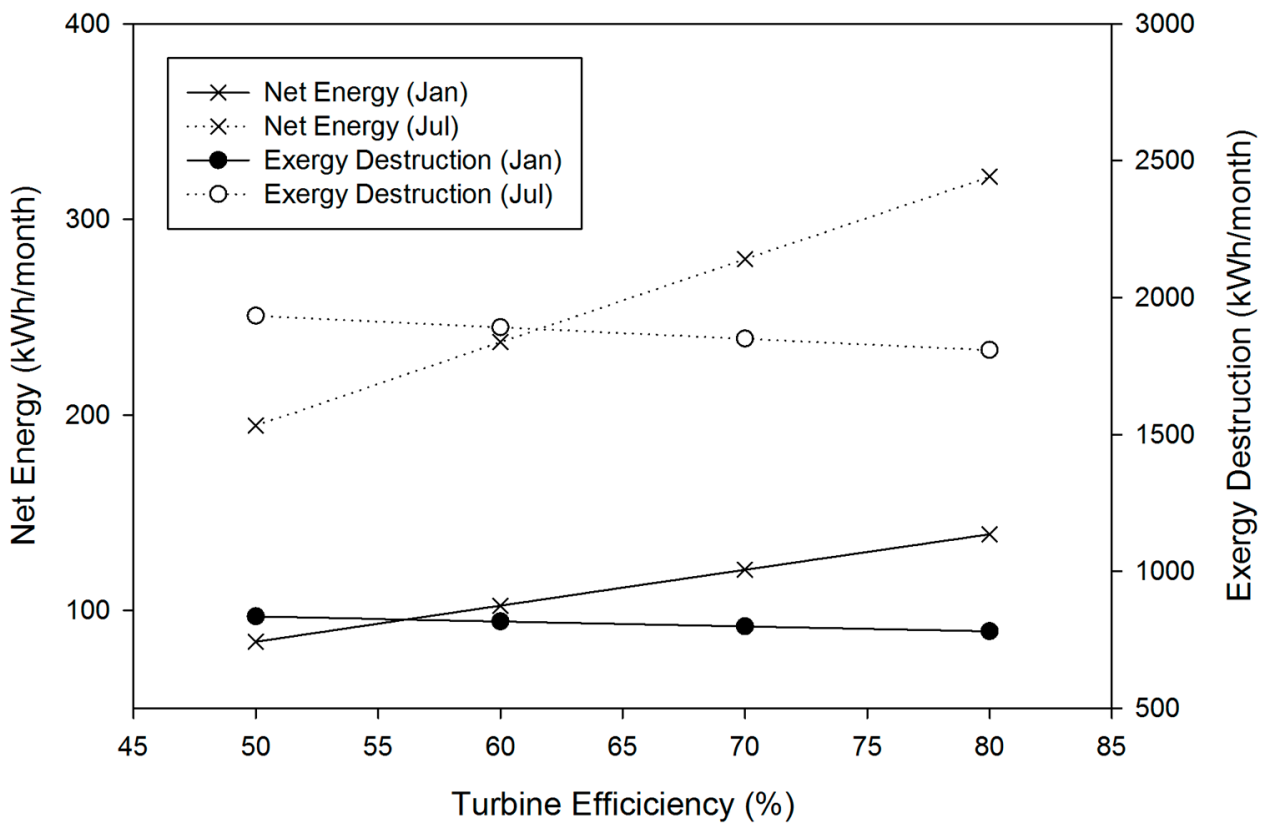

Figure 10. The effect of turbine efficiency on net energy produced and total exergy destroyed for January and July in Jackson, MS.

\section{Conclusions}

A solar powered R-ORC was investigated in this study using five dry organic fluids. The solar panels for the ORC were modeled as two axis tracking panels, and the system performance of the R-ORC and basic ORC was evaluated for Jackson, MS and Tucson, AZ. The R-ORC was compared to the basic ORC in terms thermal and exegetic efficiencies as well as PEC and CDE savings for both locations.

RC318, R227ea, R236ea, R236fa, and R218 were the fluids selected in this study. Of the evaluated fluids R236ea performed the best under the modeled conditions. R236ea produced the most net energy and destroyed the least amount of total exergy. R236ea also had the highest thermal and exergetic efficiencies. The basic ORC and the R-ORC were compared for each of the five fluids. For all of the fluids the R-ORC had higher efficiencies, produced more energy, and destroyed less total exergy than the basic ORC using the same fluid. The fluid that saw the largest percent increase of net energy produced was RC318 with a 13.3\% increase from the basic ORC net energy output. The fluid that had the largest percent decrease of the exergy destruction rate was R236ea with a 1.84\% decrease when compared with the basic ORC.

The R-ORC was modeled in Jackson, MS and Tucson, AZ to see the effect of climates on the ORC. From local weather data it was determined that Tucson received higher irradiation than Jackson. This resulted in a higher production of net energy and total exergy destroyed. Because there was more net energy produced in Tucson than Jackson, there was a larger potential for PEC and CDE savings in Tucson, AZ. The potential for PEC and CDE savings was higher for the R-ORC than the basic ORC. The ACC based on increasing average electricity costs and a payback period was also investigated for the two cities. Tucson had higher ACCs than Jackson since the electricity production from the solar powered ORC was higher in Tucson.

A parametric analysis of the R-ORC was performed to determine the effect of the intermediate pressure and the turbine efficiency. As the intermediate pressure increased, the mass flow rate of the R-ORC increased. A maximum amount of energy production and minimum amount of exergy destruction occurred when the intermediate pressure was $0.75 \mathrm{MPa}$. As the turbine efficiency increased, the net energy produced increased while the total exergy destroyed decreased. 
Author Contributions: All of the authors have contributed toward developing and implementing the ideas and concepts presented in the paper. All of the authors have collaborated to obtain the results and have been involved in preparing the manuscript.

Conflicts of Interest: The authors declare no conflict of interest.

\section{References}

1. Fang, F.; Wei, L.; Liu, J.; Zhang, J.; Hou, G. Complementary configuration and operation of a CCHP-ORC system. Energy 2012, 46, 211-220. [CrossRef]

2. Guo, T.; Wang, H.X.; Zhang, S.J. Fluids and parameters optimization for a novel cogeneration system driven by low-temperature geothermal sources. Energy 2011, 36, 2639-2649. [CrossRef]

3. Hung, T.-C. Waste heat recovery of organic Rankine cycle using dry fluids. Energy Convers. Manag. 2001, 42, 539-553. [CrossRef]

4. Hettiarachchi, H.D.M.; Golubovic, M.; Worek, W.M.; Ikegami, Y. Optimum design criteria for an Organic Rankine cycle using low-temperature geothermal heat sources. Energy 2007, 32, 1698-1706. [CrossRef]

5. Quoilin, S.; Orosz, M.; Hemond, H.; Lemort, V. Performance and design optimization of a low-cost solar organic Rankine cycle for remote power generation. Sol. Energy 2011, 85, 955-966. [CrossRef]

6. Hung, T.; Wang, S.; Kuo, C.; Pei, B.; Tsai, K. A study of organic working fluids on system efficiency of an ORC using low-grade energy sources. Energy 2010, 35, 1403-1411. [CrossRef]

7. Lakew, A.A.; Bolland, O. Working fluids for low-temperature heat source. Appl. Therm. Eng. 2010, 30, 1262-1268. [CrossRef]

8. Mago, P.J.; Chamra, L.M.; Somayaji, C. Performance analysis of different working fluids for use in organic Rankine cycles. Proc. Inst. Mech. Eng. Part A J. Power Energy 2007, 221, 255-264. [CrossRef]

9. Saleh, B.; Koglbauer, G.; Wendland, M.; Fischer, J. Working fluids for low-temperature organic Rankine cycles. Energy 2007, 32, 1210-1221. [CrossRef]

10. Wang, E.; Zhang, H.; Fan, B.; Ouyang, M.; Zhao, Y.; Mu, Q. Study of working fluid selection of organic Rankine cycle (ORC) for engine waste heat recovery. Energy 2011, 36, 3406-3418. [CrossRef]

11. Bao, J.; Zhao, L. A review of working fluid and expander selections for organic Rankine cycle. Renew. Sustain. Energy Rev. 2013, 24, 325-342. [CrossRef]

12. Rayegan, R.; Tao, Y. A procedure to select working fluids for Solar Organic Rankine Cycles (ORCs). Renew. Energy 2011, 36, 659-670. [CrossRef]

13. Mago, P.J.; Chamra, L.M.; Srinivasan, K.; Somayaji, C. An examination of regenerative organic Rankine cycles using dry fluids. Appl. Therm. Eng. 2008, 28, 998-1007. [CrossRef]

14. Branchini, L.; de Pascale, A.; Peretto, A. Systematic comparison of ORC configurations by means of comprehensive performance indexes. Appl. Therm. Eng. 2013, 61, 129-140. [CrossRef]

15. Soffiato, M.; Frangopoulos, C.A.; Manente, G.; Rech, S.; Lazzaretto, A. Design optimization of ORC systems for waste heat recovery on board a LNG carrier. Energy Convers. Manag. 2015, 92, 523-534. [CrossRef]

16. Feng, Y.; Zhang, Y.; Li, B.; Yang, J.; Shi, Y. Sensitivity analysis and thermoeconomic comparison of ORCs (organicRankine cycles) for low temperature waste heat recovery. Energy 2015, 82, 664-677. [CrossRef]

17. Le, V.L.; Feidt, M.; Kheiri, A.; Pelloux-Prayer, S. Performance optimization of low-temperature power generation by supercritical ORCs (organic Rankine cycles) using low GWP (global warming potential) working fluids. Energy 2014, 67, 513-526. [CrossRef]

18. Meinel, D.; Wieland, C.; Spliethoff, H. Economic comparison of ORC (Organic Rankine cycle) processes at different scales. Energy 2014, 74, 694-706. [CrossRef]

19. Roy, J.P.; Misra, A. Parametric optimization and performance analysis of a regenerative Organic Rankine Cycle using R-123 for waste heat recovery. Energy 2012, 39, 227-235. [CrossRef]

20. Li, M.; Wang, J.; He, W.; Gao, L.; Wang, B.; Ma, S.; Dai, Y. Construction and preliminary test of a low-temperature regenerative Organic Rankine Cycle (ORC) using R123. Renew. Energy 2013, 57, $216-222$. [CrossRef]

21. Mago, P.J.; Srinivasan, K.K.; Chamra, L.M.; Somayaji, C. An examination of exergy destruction in organic Rankine cycles. Int. J. Energy Res. 2008, 32, 926-938. [CrossRef] 
22. Imran, M.; Park, B.S.; Kim, H.J.; Lee, D.H.; Usman, M.; Heo, M. Thermo-economic optimization of Regenerative Organic Rankine Cycle for waste heat recovery applications. Energy Convers. Manag. 2014, 87, 107-118. [CrossRef]

23. Fumo, N.; Chamra, L.M. Analysis of combined cooling, heating, and power systems based on source primary energy consumption. Appl. Energy 2010, 87, 2023-2030. [CrossRef]

24. Mago, P.J.; Hueffed, A.; Chamra, L.M. Analysis and optimization of the use of CHP-ORC systems for small commercial buildings. Energy Build. 2010, 42, 1491-1498. [CrossRef]

25. Lecompte, S.; Huisseune, H.; van den Broek, M.; de Schampheleire, S.; de Paepe, M. Part load based thermo-economic optimization of the Organic Rankine Cycle (ORC) applied to a combined heat and power (CHP) system. Appl. Energy 2013, 111, 871-881. [CrossRef]

26. Calise, F.; Capuozzo, C.; Carotenuto, A.; Vanoli, L. Thermoeconomic analysis and off-design performance of an organic Rankine cycle powered by medium-temperature heat sources. Sol. Energy 2014, 103, 595-609. [CrossRef]

27. Quoilin, S.; Declaye, S.; Tchanche, B.F.; Lemort, V. Thermo-economic optimization of waste heat recovery Organic Rankine Cycles. Appl. Therm. Eng. 2011, 31, 2885-2893. [CrossRef]

28. Feng, Y.; Zhang, Y.; Li, B.; Yang, J.; Shi, Y. Comparison between regenerative organic Rankine cycle (RORC) and basic organic Rankine cycle (BORC) based on thermoeconomic multi-objective optimization considering exergy efficiency and levelized energy cost (LEC). Energy Convers. Manag. 2015, 96, 58-71. [CrossRef]

29. Tempesti, D.; Manfrida, G.; Fiaschi, D. Thermodynamic analysis of two micro CHP systems operating with geothermal and solar energy. Appl. Energy 2012, 97, 609-617. [CrossRef]

30. Wang, X.; Zhao, L.; Wang, J.; Zhang, W.; Zhao, X.; Wu, W. Performance evaluation of a low-temperature solar Rankine cycle system utilizing R245fa. Sol. Energy 2010, 84, 353-364. [CrossRef]

31. Calise, F.; d'Accadia, M.D.; Vicidomini, M.; Scarpellino, M. Design and simulation of a prototype of a small-scale solar CHP system based on evacuated flat-plate solar collectors and Organic Rankine Cycle. Energy Convers. Manag. 2015, 90, 347-363. [CrossRef]

32. Rayegan, R.; Tao, Y.X. Optimal Collector Type and Temperature in a Solar Organic Rankine Cycle System for Building-Scale Power Generation in Hot and Humid Climate. J. Sol. Energy Eng. 2013, 135. [CrossRef]

33. Marion, M.; Voicu, I.; Tiffonnet, A.L. Study and optimization of a solar subcritical organic Rankine cycle. Renew. Energy 2012, 48, 100-109. [CrossRef]

34. Wang, M.; Wang, J.; Zhao, Y.; Zhao, P.; Dai, Y. Thermodynamic analysis and optimization of a solar-driven regenerative organic Rankine cycle (ORC) based on flat-plate solar collectors. Appl. Therm. Eng. 2013, 50, 816-825. [CrossRef]

35. Pei, G.; Li, J.; Ji, J. Analysis of low temperature solar thermal electric generation using regenerative Organic Rankine Cycle. Appl. Therm. Eng. 2010, 30, 998-1004. [CrossRef]

36. Spayde, E.; Mago, P.J. Evaluation of a solar-powered organic Rankine cycle using dry organic working fluids. Cogent Eng. 2015, 2. [CrossRef]

37. Xu, G.; Song, G.; Zhu, X.; Gao, W.; Li, H.; Quan, Y. Performance evaluation of a direct vapor generation supercritical ORC system driven by linear Fresnel reflector solar concentrator. Appl. Therm. Eng. 2015, 80, 196-204. [CrossRef]

38. Alternate Energy Technologies. Certified Solar Collector. Available online: http://www.aetsolar.com/ certifications.php (accessed on 1 April 2014).

39. Hodge, B.K. Alternative Energy Sources and Applications; Wiley: New York, NY, USA, 2009.

40. National Solar Radiation Data Base. Available online: http://rredc.nrel.gov/solar/old_data/nsrdb/19912005/tmy3/ (accessed on 4 April 2014).

41. Solar Energy Research Institute. Engineering Principles and Concepts for Active Solar Systems; CRC Press: Springfield, VA, USA, 1987.

42. Duffie, J.A.; Beckman, W.A. Solar Engineering of Thermal Processes; John Wiley \& Sons: New York, NY, USA, 1980.

43. Hepbasli, A. A key review on exergetic analysis and assessment of renewable energy resources for a sustainable future. Renew. Sustain. Energy Rev. 2008, 12, 593-661. [CrossRef]

44. Czachorski, M.; Leslie, N. Source Energy and Emission Factors for Building Energy Consumption. Available online: https://www.aga.org/codes-and-standards-research-consortium (accessed on 15 September 2014). 
45. Energy Star. Energy Star Portfolio Manager Technical Reference Source Energy. Available online: https: //portfoliomanager.energystar.gov/pdf/reference/Source\%20Energy.pdf (accessed on 12 July 2016).

46. Deru, M.; Torcellini, P. Source Energy and Emission Factors for Energy Use in Buildings. Available online: www.nrel.gov/docs/fy07osti/38617.pdf (accessed on 15 September 2014).

47. Power Profiler. Available online: http://oaspub.epa.gov/powpro/ept_pack.charts (accessed on 20 August 2014).

48. U.S. Energy Information Administration. Electric Power Monthly with Data for March 2016. Available online: http:/ / www.eia.gov/electricity/monthly/current_year/may2016.pdf (accessed on 13 July 2016).

49. Lemmon, E.W.; Huber, M.L.; McLinden, M.O. REFPROP: Reference Fluid Thermodynamic and Transport Properties; Version 9.1; National Institute of Standards and Technology: Gaithersburg, MD, USA, 2013.

(C) 2017 by the authors; licensee MDPI, Basel, Switzerland. This article is an open access article distributed under the terms and conditions of the Creative Commons Attribution (CC-BY) license (http:/ / creativecommons.org/licenses/by/4.0/). 